\title{
From Greek antiquity to the middle ages: a possible incursion on special interest tourism in the Danube Delta
}

\author{
G. Romanescu ${ }^{1}$, O. Bounegru ${ }^{1} \&$ V. Efros ${ }^{2}$ \\ ${ }^{1}$ University of Iasi, Romania \\ ${ }^{2}$ University of Suceava, Romania
}

\begin{abstract}
The Danube Delta is the newest landform within the Romanian territory. In 1992 it was declared a Biosphere Reservation (UNESCO patrimony), the only delta on the globe in this category. The natural resources (landscape, animal and vegetation, water bodies, etc.) and the cultural inheritance (historical vestiges, traditional architecture, customs, etc) are part of the Danube Delta - the most important tourism area in Romania. If, in the Communist period, the Romanians were the ones mainly visiting the delta, in the current context there are ever more foreign tourists (German, Austrian, French, Spanish, Italian, etc.). Unfortunately, the tourism development plans do not fully target the cultural exploitation of the region. This is the reason for proposing a tourist exploitation of the ancient and mediaeval inheritance, since the historical vestiges of Dobroudja are extremely rich, being at the limit between the continental land and the deltaic area. The 17 proposed objectives (ancient and mediaeval cities) can be visited in two ways: by land and by water. The Bisericuta city can only be visited by water and the Ibida city only by land. Such an itinerary may be combined with other forms of tourism, or it may be considered specialist tourism for archaeologists, historians, art historians, and students in the field (history, geography, architecture, etc.). It is the first such itinerary proposed in the area of the Danube Delta Biosphere Reservation. The tourist exploitation of all the resources within the area of the Danube Delta will inevitably lead to an increase in the incomes of the local population and of the particular institutions. On the territory of the Danube Delta Biosphere Reservation ecologically responsible tourism will be practiced. The nodal point of all tourist destinations within the Danube Delta is the town of
\end{abstract}


Tulcea (the former city of Aegyssus), endowed with an infrastructure which can satisfy even the most exigent tastes.

Keywords antiquity, Danube Delta Biosphere Reservation, middle ages, Romania, specialist tourism

\section{Introduction}

The Romanian post-Communist economy has had a relatively slow evolution. This is why most economic sectors have stagnated or regressed. The only fields to offer hope have remained agriculture and tourism.

If in agriculture the results have already appeared, mostly during the last three years, it seems that tourism has to wait. During the last 10 years, the tourism for infrastructure has improved and there are now high quality services. Nevertheless, the number of foreign tourists is still small. This is due to the poor promotion of Romanian tourism and to a preconceived idea of Romanians' behaviour, as well as to anti-Romanian propaganda within certain Western circles.

The preoccupations within the international specialist tourism are numerous [1-18].

Most preoccupations in the field of the deltaic tourism in general [19-20] and of the specialist tourism in particular [23-25] have brought to the attention of the public the most important touristic areas on Earth: Danube, Mississippi, Okavango, Mekong, etc. For the Danube Delta the most remarkable papers are those in the field of tourism geography [26-34]. There are also important papers on deltaic archaeology [35-44].

\section{Regional setting}

The Danube Delta is situated in the northeast of Romania and in the northwest of the Black Sea, at the State border with Ukraine (north) (Figure 1).

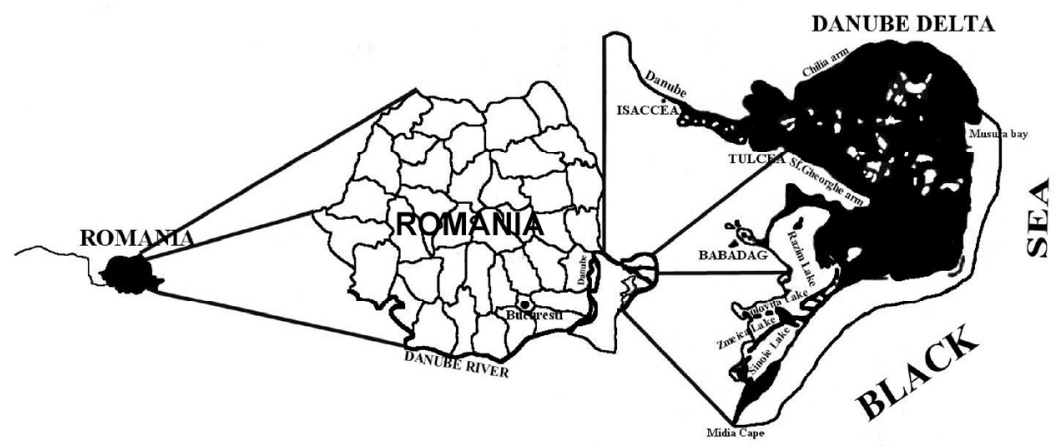

Figure 1: Geographical location of the Danube Delta Biosphere Reservation on Romanian territory. 
The actual area of the Danube Delta is $4,455 \mathrm{~km}^{2}$ and most of it spreads across Romanian territory, i.e. $3,510 \mathrm{~km}^{2}(84 \%)$. The former Halmyris bay area, where the Razim-Sinoie Lake was created, is $1,015 \mathrm{~km}^{2}$ (of which lakes represent $863 \mathrm{~km}^{2}$ ), and together the two geographical units cover an area of $5,470 \mathrm{~km}^{2}[28]$.

The geographical coordinates marking the delta space limits are between $44^{\circ} 47^{\prime}$ (peak of the Perişor sand levee) and 45 $37^{\prime}$ (Lake Sasik shore - Ukraine) northern latitude, and between 28 44' (Ceatalul Chilia) and 29 46' (East end of the secondary Delta of the Ukraine, Chilia arm) eastern longitude.

The geographical coordinates of the Razim-Sinoie lacustrine complex are the following: $44^{\circ} 20^{\prime}$ (Cape Midia) and $45^{\circ} 02^{\prime}$ ' (Agighiol village) North and $28^{\circ} 40^{\prime}$ (Satu Nou village, on the shore of Topraisar lake) and 29 09' (Periteaşca fishery from the top of the Perisor sand levee) eastern longitude [32-33].

\section{Methods and techniques}

Statistical data on tourist flows and upon the development of and tourism exploitation propositions in the Danube Delta were taken from the Administration of the Danube Delta Biosphere and from the Danube Delta National Institute for Research and Development in Tulcea.

In order to propose a tourist itinerary, exploiting the ancient and mediaeval cultural heritage, the cartographic tool developed by the Geoarchaeology Laboratory of the Faculty of Geography and Geology in Iasi was used (director Prof. Romanescu Gheorghe, PhD). The entire cartographic material was processed in CorelDRAW 12 and Paint Shop Pro 7.

The Institute for Eco-Museum Research Institute in Tulcea provided the history-related data; the National Institute of Statistics, as well as the city halls, helped with the statistical data.

The bibliography consulted was extremely rich and, eventually, we have focused on papers representing a scientific endeavour from a geographic, historical, economic, demographic, ecologic, etc. perspective.

\section{Results and discussion}

\subsection{Tourism potential and forms of tourism}

The natural and cultural tourism potential of the Danube Delta is extremely varied. The economic reorganisation of Romania determined the exploitation of the most diverse sources of revenues. From this perspective, the Danube Delta has been more and more pressured; tourism is one of the most viable economic branches [23]. The main idea is that of practicing eco-tourism, applied to all forms of expression [4, 22, 45].

The development of deltaic tourism is also a consequence of current cruise tourism on the Danube valley, from Germany to its mouths (Figure 2).

The status of Biosphere Reservation determined the delimitation of certain strictly protected areas, where no one can run economic activities and only 


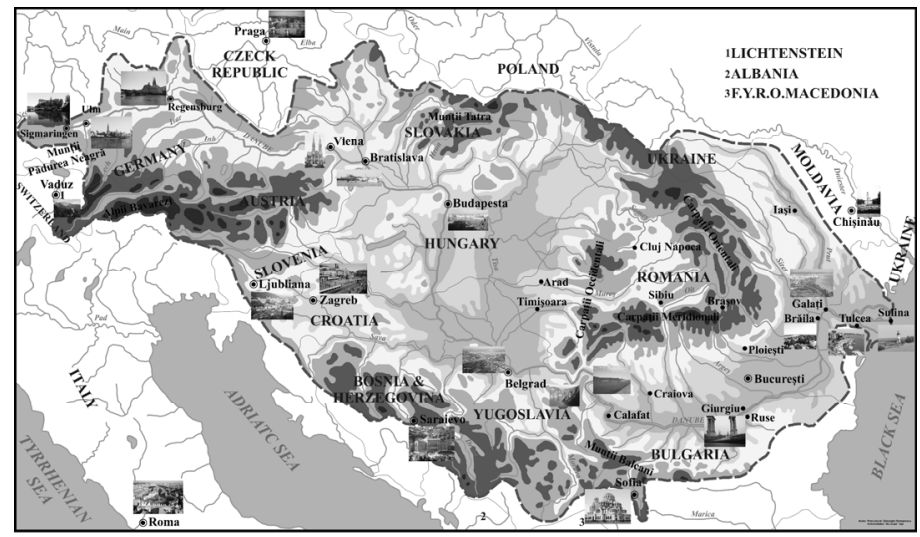

Figure 2: The Danube hydrographic basin and the emphasis on the most important cities on its course.

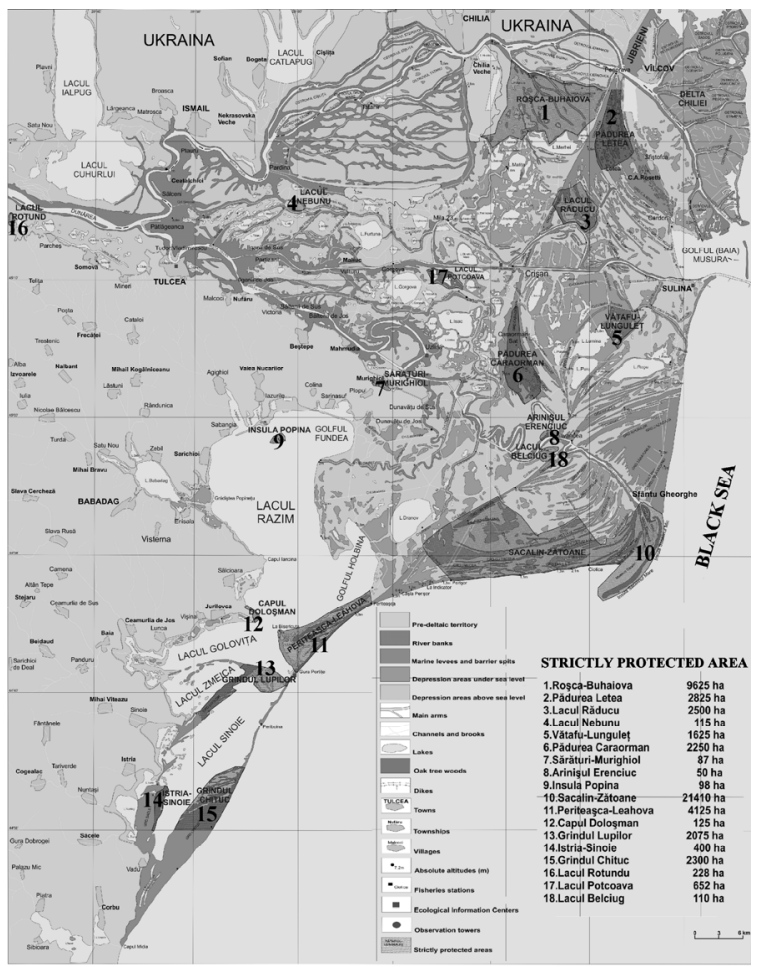

Figure 3: Map of the strictly protected areas within the Danube Delta Biosphere Reservation.

specialists are allowed. In this way 18 strictly protected areas were determined, with the role of preserving biodiversity [26, 28, 31, 32] (Figure 3). 
The main forms of tourism on the territory of the Danube Delta Biosphere Reservation are the following:

1. Tourism for relaxation and recreation. Domestic or foreign tourism companies mediate it. The infrastructure within the reservation or on the Dobroudjan continental frame is used. Excursions are organised on the main arms, channels, lakes, in rural or urban settlements (Tulcea, Sulina) and on the coast.

2. Knowledge (itinerant) tourism. It is practiced at the level of specialised organisations or individually. It is ideal for small groups, specialising in ecological tourism. There is a combination of walks with traditional or modern boats. Short trips may also be organised along the fluvial or fluvio-marine grinds (Sulina, Crisan, St. George, Murighiol, Periprava, C.A. Rosetti, Mila 23, Uzlina, etc.).

3. Scientific tourism. This is a special interest tourism form, targeting botanists, ornithologists, specialists in various fields, researchers, students (for their graduation, master, or $\mathrm{PhD}$ thesis), etc. Every year, the city of St. George organises the "Anonimus" International Film Festival, the reason for which several luxury hotels, functioning in a closed-circuit arrangement, were built. The itinerary proposed as an alternative for practicing niche tourism is also part of this category.

4. Special youth programs. Their purpose is to know, understand, and preserve nature within the Danube Delta Biosphere Reservation.

5. Rural tourism. Locals guide the tourists; the latter are welcomed to traditional, rural households. It represents the most important income for most of the population in the Danube Delta. The best locations are at St. George, Mila 23, Periprava, Crisan, etc.

6. Tourism for sailing, photo-safari, etc. There are special places for this type of tourism, mostly on the Black Sea coast (Portita, St. George, Sulina).

7. Tourism for sports fishing and hunting. It is allowed during all seasons, except for prohibited periods.

Tourism in the Danube Delta Biosphere Reservation is conditioned by certain access rules, imposed by the status of the protected area [46]:

1. The tourism activities in the Danube Delta Biosphere Reservation (RBDD) are authorised by the Regulation - Authorisation - Development Service within the ARBDD.

2. Tourists will be allowed into the Danube Delta Biosphere Reservation only on the grounds of an access permit, obtained from the ARBDD Tulcea, after paying a permit fee.

3. Tourism in the Danube Delta Biosphere Reservation will follow the approved itineraries, which exclude the tourists' access to areas under an integral protection regime.

4. The ARBDD recommends using local guides on approved itineraries.

5. The ARBDD recommends using small boats, with electric propulsion.

6. Access outside the main itineraries will only be granted for traditional, rowing boats.

7. Camping is only allowed in approved areas. 
8. The floating hotels, used to lodge and transport tourists, have to include hopper tanks for liquid waste and bins for rubbish.

9. The tourist transport ships have to include special systems for waste and rubbish collection.

10. Individual tourists have to take with them, upon leaving, all plastic, paper, metals, or glass used from the food they consumed.

11. Tourists are not allowed in the areas of bird colonies.

12. The ARBDD recommends using ornithological towers for bird watching.

13. It is forbidden to cut trees or to cull flowers of any kind.

14. Only the fishing associations, legally constituted, can organise sports fishing, practicing it only in approved areas.

15. Only the hunting associations, legally constituted, can organise sports hunting, within the authorised areas.

There are three information, documentation, and ecological education centres within the structure of the ARBDD: Tulcea, Crisan, and Sulina.

\subsection{Tourism itineraries on the Danube Delta Biosphere Reservation territory}

The Danube Delta Biosphere Reservation Administration proposed 19 itineraries on water and 7 itineraries on land.

Tourism itineraries on navigable routes:

Itinerary no. 1: Tulcea - Mila 35 channel - Sireasa brook - Olguţa channel Dunarea Veche - Mila 23 village-Crisan - Maliuc - Tulcea.

Itinerary no. 2: Tulcea - Litcov channel - Crisan channel - Caraorman Lebada Hotel - Maliuc - Tulcea.

Itinerary no. 3: Tulcea - Maliuc - Lebada Hotel - Crisan channel Caraorman - Puiu Lake - BTT Rosu halt - Red Lake - Imputita - Busurca channel - Sulina - Tulcea.

Itinerary no. 4: Murighiol - Dunavat channel - Dranov - Holbina channel Razim Lake - Gura Portitei.

Itinerary no. 5: Jurilovca - Gura Portitei.

Itinerary no. 6: Lebada Hotel - Dunarea Veche - Eracle channel - Lopatna brook -Lopatna channel - Trei Iezere Lake.

Itinerary no. 7: Lebada Hotel - Dunarea Veche - Magearu - Dunarea Veche Sulina arm - Lebada Hotel.

Itinerary no. 8: Tulcea - Chilia Veche on the route: Tulcea - Mila 36 channel - Sireasa channel - Sontea channel - Razbolnita channel - Stipoc channel Pardina channel - Chilia Veche.

Itinerary no. 9: Chilia tour on the route: Chilia Veche - Chilia arm - Babina arm -Cernovca arm - Sulimanca channel - Merheiul Mic Lake - Merhei Lake Matita Lake - Babina Lake - Radacinoasele channel - Pardina channel - Chilia Veche.

Itinerary no. 10: St. George tour on the route: St. George - Zaton channel Buhaz channel - Palade channel - Crasnicol channel - St. George arm - St. George. 
Itinerary no. 11: Sulina - Periprava itinerary on the route: Sulina - Cardon channel -Sfistofca channel - Periprava.

Itinerary no. 12: Sulina - Periprava itinerary on the route: Sulina - Cardon channel -Musura Gulf - Musura arm - Stambulul Vechi arm - Chilia arm Periprava.

Itinerary no. 13: Uzlina tour on the route: Uzlina - Uzlina channel - Uzlina Lake - Isac Lake - Isac 3 channel - Perivolovca brook - St. George arm Uzlina - with extension, Isac Lake - Isac 2 channel - Litcov channel Ceamurlia channel - Crisan channel - Sulina arm -Crişan Centre for Ecological Information and Documentation.

Itinerary no. 14: Jurilovca - Periboina - Istria itinerary on the route: Jurilovca - Golovita Lake - channel V - Sinoie Lake - Periboina fishery - city of Istria channel II - Zmeica Lake -Golovita Lake - Jurilovca.

Itinerary no. 15: Tulcea - Mila 23 itinerary on the route: Tulcea - Sulina arm - Mila 22 channel - Sontea brook - Dunarea Veche - Mila 23.

Itinerary no. 16: Crisan - Mila 23 itinerary on the route: Crisan - Dunarea Veche - Bogdaproste channel - Bogdaproste Lake - La Amiaza Lake - Trei Iezere Lake - Lopatna brook - Eracle channel - Dunarea Veche - Mila 23.

Itinerary no. 17: Sulina - St. George itinerary on the route: Sulina - Busurca channel - Imputita channel - coastal barrier - Tataru - St. George.

Itinerary no. 18: Sulina - St. George itinerary on the route: Sulina - Busurca channel - Red channel - Imputita - Rosulet Lake - Rosulet fishery- Red Lake Red tourist base - Puiu Lake - Mocansca channel - Erenciuc channel - St. George arm - St. George.

Itinerary no. 19: Casla Lake - Somovei brook - Potica Lake - Parches Lake Telincea Lake.

Guided tours will be organized on the emerged lands on the following itineraries: D.1 itinerary: Letea - C.A. Rosetti - Letea forest - Nebunu Lake and back; D.2 itinerary: Sfistofca - C.A. Rosetti - Nebunu Lake - and back; D.3 itinerary: Caraorman - Caraorman forest - Erenciuc Lake - and back; D.4 itinerary: Murighiol - Saraturi Lake - and back; D.5 itinerary: Uzlina - Uzlina Lake - and back; D.6 itinerary: Tudor Vladimirescu - Sireasa brook - and back; D.7 itinerary: Nuntasi Lake - city of Istria - Sinoie Lake - and back.

The tourism infrastructure serving the Danube Delta Biosphere Reservation is not properly developed and cannot cope with the entire demand at European standards. Despite all the shortcomings at the present time, the Danube Delta remains a relatively expensive tourist area, the reason for which there are fewer tourists now than during the Communist period. Nevertheless, the incomes have increased because the tourists of the new wave are more educated. In this way, the environmental protection is also ensured.

Yet, the changes in the tourism infrastructure of the Danube Delta are radical. Until 2000, there were only a few four or five star hotels for lodging. Most lodging places were the houses of inhabitants, most of those being within the agro-tourism villages [29]. After 2000, investments in infrastructure started, mainly in the area surrounding the Danube Delta Biosphere Reservation. At this time, more lodging places became available, mostly in four or five stars hotels 
and four or five daisies guesthouses (the flower system is used for the classification of the Romanian guesthouses in agritourism).

The entire infrastructure includes 22 hotels (one five star hotel - Parches; five four star hotels - Delta, Egreta, Mon Jardin, Rex; 10 three star hotels; three two star hotels; one 1 star hotel; and two tourism complexes); 19 floating hotels; 20 pensions in the ANTREC network (six two daisy pensions; 12 three daisy pensions; one four daisy pension; and one five daisy pension - Morena). It also comprises 56 other pensions ( 3 at Tulcea, 7 at Sulina, 8 at Crisan, 1 at MaliucGorgova, 9 at Mila 23, 1 at Caraorman, 5 at Gorgova-Vulturu, 12 at St. George, 2 at Murighiol, 1 at Mahmudia, 4 at Dunavatu de Jos, 1 at Jurilovca, 1 at Sarichioi, 1 at Chilia Veche and 1 at Nufaru. The only five star resort within the Danube Delta operates at Parches.

There are four authorised camp sites (VITAL Chilia - 40 places; DELFINUL St. George; CORMORAN Uzlina; PELICAN Murighiol) and four vacation villages (LA EDEN Gura Portitei; Red, between the Sulina and the St. George arms; NUFARUL Partizani; and BAKO Murighiol).

This tourism infrastructure also includes three school camps: "The Danube Delta" Sulina, Bididia-Tulcea, and Babadag.

The Danube Delta remains the outstanding brand of Romanian tourism, even though other national parks may have more visitors. The Danube Delta attracts the largest number of foreign tourists, most of who come for specialist tourism, which is usually expensive.

The national parks and reservations in Romania attract 2,300,000 visitors [11]. Among them the most important are the following: The Bucegi Natural Parks $(1,000,000$ visitors), Vanatori Neamt $(400,000)$, Apuseni $(300,000)$, the Danube Delta Biosphere Reservation (96,090 tourists lodged), the Iron Gates $(60,000)$, Putna-Vrancea $(40,000)$, and the Piatra Craiului Natural Parks $(80,000)$, Semenic - Cheile Carasului $(60,000)$, Cozia $(50,000)$, as well as Ceahlau (33,000). Nevertheless, the Danube Delta Biosphere Reservation registers the largest number of tourists using tourist accommodation infrastructures, the area being objectively controlled.

All the tourists received in the Danube Delta Biosphere Reservation (96,090 tourists lodged in 2008, including in the city of Tulcea) fall into the following categories: $82 \%$ Romanian and $18 \%$ foreign tourists. Of the foreign tourists, 29.8\% are German, 9.6\% Italian, 8.0\% Spanish, 7.3\% French, 6.9\% Austrian, and $38.4 \%$ - other nationalities. Of the total number of tourists, $70.5 \%$ lodge in hotels $(60.4 \%$ choose a three star location). The average duration of the stay is 1.8 days (for both Romanians and foreigners) [11].

In all the tourism development plans of the Danube Delta Biosphere Reservation, there is no project targeting specialised tourists, for the ancient and mediaeval cultural inheritance (archaeological). This is why such an itinerary is proposed for the very first time (Figure 4). It strictly depends on the archaeological specialisation, but it can also be combined with other types of tourism. 
It is the only large itinerary of this type that can be followed on two different routes: by land and by water. The exceptions are the cities of Bisericuta (only by water) and Ibida (only by land), but the distances are insignificant and not tiresome.

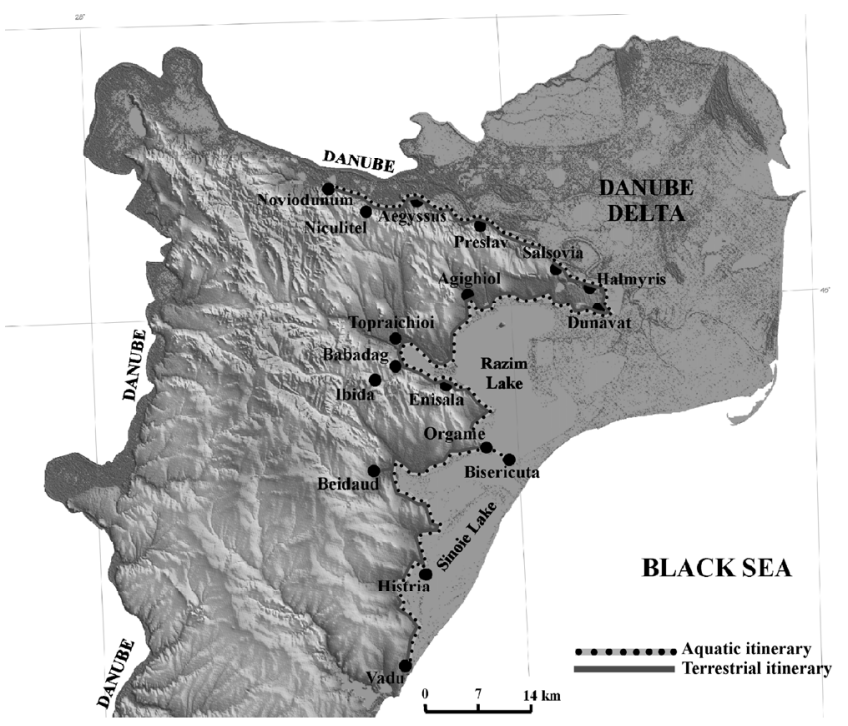

Figure 4: Proposition of a specialised tourism itinerary to exploit the ancient and mediaeval cultural inheritance of the Danube Delta Biosphere Reservation.

The targets were the most important objectives, which have been (most of them) determined and studied. Another part, rather important, is yet to be explored and it represents a potential to be exploited in the near future.

The 17 ancient and mediaeval objectives are as follows: Noviodunum ancient Roman, Byzantine and mediaeval city; the ancient crypt with saints at Niculitel; Aegyssus - ancient Roman city; Preslav - Byzantine city; Salsovia ancient Roman city; Halmyris - ancient Roman city; Dunavat - ancient Roman fortification; Agighiol - grave of a Thracian prince; Toprachioi (Babadag) Roman fortification and supply point; Babadag - Thracian and Roman fortification; Ibida - ancient Roman city; Enisala (Heraclea) - Genovese mediaeval city; Beidaud - Thracian fortification; Bisericuta - Roman fortification; Orgame (Argamum) - ancient Greek and Roman city; Histria ancient Greek city; Vadu - Ottoman fortification.

The special interest tourist itinerary proposed may be combined with other itineraries in the near vicinity because it is situated at the limit between the continental land and the deltaic area. Nowadays, the road infrastructure is adequate, and the nautical one can satisfy all demands. The Danube course, on the Tulcea arm, the St. George arm, the Dunavat channel, and the mirror of the Razim-Sinoie lagoon complex accompany the entire itinerary proposed. Along 
the entire itinerary, or in the near vicinity (Parches, Tulcea, Mahmudia, Murighiol, Lunca, Jurilovca, Portita, Mamaia, Constanta, etc.), there are hotels and pensions which can house a relatively large number of tourists.

Within the proposed itinerary there are also two tourism objectives with a special religious significance for the Christianisation of the Romanian people. At Halmyris and Niculitel, the reliquae of the oldest Christian saints in Romania and in southeastern Europe, were discovered $\left(2^{\text {nd }}-4^{\text {th }}\right.$ centuries $\left.A D\right)$. From this perspective, the specialist tourism ideally combines with a religious one.

The tourism potential of the area and of the proposed itinerary will definitely grow when it will be demonstrated that the legendary island of "Peuce" was part of the territory occupied today by the Dunavat Peninsula (where the cities of Salsovia and Halmyris are located).

\section{Conclusions}

The Danube Delta Biosphere Reservation benefits from a special status in comparison to the other natural parks in Romania. It has been included in UNESCO and it is the only such delta on Earth. From this perspective, these wetlands represent a major tourist attraction for special interest tourism.

Besides the natural and cultural setting, specific to deltaic units, near the Danube Delta Biosphere Reservation, there are also important ancient (Thracian, Roman, Byzantine) and mediaeval (Genovese, Ottoman) historic vestiges. Unfortunately, their tourism potential has not yet been fully exploited. The Danube Delta Biosphere Reservation, the Danube Delta National Institute for Research and Development, or other specialised institutions within the country and abroad have not taken into account the specialized tourism potential of these objectives. This is why a tourism exploitation itinerary was proposed for the ancient and mediaeval objectives on the territory of the Danube Delta Biosphere Reservation and in the near vicinity.

The special interest tourism and the chosen itinerary can be included in sustainable tourism management specific to the natural reservations, and it can contribute to an increase in the level of education of the population, as well as to the development of the local economy.

\section{Acknowledgements}

Our thanks go to the Geo-archaeology Laboratory within the Faculty of Geography and Geology, "Alexandru Ioan Cuza" University of Iasi, which provided the tools and carried out the data processing.

The Ministry of Education and Research paid for the measurements and the publication through CNCS grant no. 0857 (216), for the period 2011-2014, with Professor Bounegru Octavian, $\mathrm{PhD}$, as a grant director. 


\section{References}

[1] Boniface, G.B. \& Cooper, C., The geography of travel and tourism, Buttervorth - Heinemann Ltd.: UK, 1994.

[2] Brohman, J., New directions in tourism for Third World development, Annals of Tourism Research, 23, pp.48-70, 1996.

[3] Butler, R., The concept of a tourism area cycle of evolution: the implications for management of resources, Canadian Geographer, 24(1), pp.5-12, 1980.

[4] Engles, P.F.J., McCool, S. \& Haynes, C.D.A., Sustainable Tourism in Protected Areas: Guidelines for Planning and Management, IUCN Glands: Switzerland, Cambridge, UK., 2002.

[5] Ghimire, K.B. (Editor), 2001, The native tourist. Mass tourism within developing countries, Earthscan Publications Ltd.: United Kingdom, 2001.

[6] Harrison, D. (Editor), International tourism and the less developed countries: the background, Halsted Press: New York, Toronto, 1992.

[7] Marcussen, C-H., Trends in European Internet Distribution of Travel and Tourism Services, Version 2, www.crt.dk/uk/staff/chm/trends.htm, 2001.

[8] Mathieson, A. \& Geoffrey, W., Tourism economic, physical and social impacts, Longman Group Limited: London, New York, 1982.

[9] Oppermann, M., Tourism space in developing countries, Annals of Tourism Research, 22(1), pp.151-171, 1993.

[10] Organisation Mondiale du Tourisme (OMT/WTO), General Guidelines for the Development of Foreign Direct Investment indicators on the Tourism Sector, Tourist Satellite Account Implementation Project (Madrid: OMT), 2004.

[11] Tudorache, D., National strategy for ecotourism development in Romania. Phase I., National and international ecotourism experience, National Institute of Research-Development in Tourism: Bucharest, 2009.

[12] UNCTAD, International trade in tourism related services: Issues and options for developing countries, United Nations: New York, Geneva, 1998.

[13] UNCTAD, Recent Developments in Trade and Competition Issues in the Services Sector: a Review of Practice in Travel and Tourism, United Nations: Geneva, 1999.

[14] UNCTAD, FDI in Tourism: The Development Dimension, United Nations: New York, Geneva, 2007a.

[15] UNCTAD, FDI, tourism and developing countries - Selected developing country case-studies, New York, Geneva, United Nations: New York, Geneva, 2007b.

[16] UNWATO, Searching for the Holy Grail? Making work for sustainable development, Background paper, World Wildlife Fund for Nature: Gland, Switzerland, 2003.

[17] UNWTO, Making Tourism More Sustainable - A Guide for Policy Makes, Madrid, Spain, 2005. 
[18] WTO/OMT, Tourism 2010 Vision: Global Forecast and Profiles of Market Segments, 7, Madrid, WTO/OMT, Madrid, 2001.

[19] Hyland, S.E., Tourism in the Lower Mississippi Delta: Whose Field of Dreams? The Struggle Among The Landed Aristocracy, The Grass-Roots Indigenous and The Gaming Industry, In: Tourism and Culture. An Applied Perspective (E. Chambers Editor), State University of New York Press: Albany, pp.147-160, 1997.

[20] Mbaiwa, J., The socio-economic and environmental impacts of tourism in the Okavango Delta, north/west Botswana, Journal of Arid Environments, 54, pp.447-467, 2003.

[21] Mbaiwa, J., The socio-cultural Impacts of Tourism Development in The Okavango and Cultural Change, Journal of Tourism and Cultural Change, 2(3), pp. 63-185, 2005. Doi: 10.1080/14766820508668662.

[22] Mbaiwa, J., Transboundary Diagnostic Analysis of the Okavango River Basin. The Status of Tourism Development in the Okavango Delta, Botswana, OKACOM: University of Botswana, 2009.

[23] Glavan, V., Tourism in the Danube Delta Biosphere Reservation, Romanian Tourism Journal, 1(4), pp. 30-34, 1994.

[24] Leone, M.P., The role of Archaeology in Verifying American Identity: Given a Tour Based on Archaeological Method, Archaeological Review From Cambridge, 2(1), pp. 44-50, 1983.

[25] Nitu, M., Tourism in the Danube Delta, Sport-Turism: Bucharest, 1982.

[26] Baboianu, G. \& Goriup, P., Management objectives for the conservation of biodiversity and for the sustainable development of the Danube Delta Biosphere Reservation - Romania, Information: Newbury, UK., 1998.

[27] Blumer, A., Lang, A. \& Benabdallah, J., Zoning for recreation and tourism in $R B D D$ - Component of the tourism and management strategy for visitors, Detente Company/Consultants, Ecotourism Association in Romania: Bucharest, 2009.

[28] Gastescu, P. \& Baboianu, G., Danube Delta Biosphere Reserve. Visitor's Guide, Danube Delta Biosphere Reservation Administration: Tulcea, 2011.

[29] Light, D. \& Dumbraveanu, D., Romanian tourism in the post-communist period, Annals of Tourism Research, 26(4), pp. 898-927, 1999. Doi: 10.1016/SO 160-7383(99)00033-X.

[30] Meita, V., Habitat architecture in the Danube Delta, Editura Universitatii Ion Mincu: Bucharest, 2003.

[31] Romanescu, G., The Danube Delta. Tourist guide. Corson: Iaşi, 1997.

[32] Romanescu, G. \& Romanescu, Gabriela, Dobrudja. Tourist resources, Helios: Iasi, 1998.

[33] Romanescu, G., Morpho-hydrographical evolution of the Danube Delta, II, Management of water resources and coastline evolution. Land use and the ecological consequences, TERRA NOSTRA: Iaşi, 2005.

[34] Romanescu, G., The Razim-Sinoie lagoon complex. Morpho-hydrographic study, “Al.I.Cuza” University Publishing House: Iasi, 2006. 
[35] Baumann, V.H., Ancient rural settlements in the area of the Danube mouths. Archaeological contributions to the knowledge of rural habitat $\left(2^{\text {nd }}-4^{\text {th }}\right.$ centuries AD), ICEM Archive: Tulcea, 1995a.

[36] Baumann, V.H., Archaeological research in the area of the Paleo-Christian ensemble in the Niculitel commune, Tulcea County, Peuce, 11, pp.133-141, 1995b.

[37] Bounegru, O., Representation de naves actuariae sur la cote ouest de la Mer Noire, Studia Antiqua et Archaeologica, II, 1995.

[38] Bounegru, O., La flote militaire et comerciale romaine au bas-Danube et au pont gauche, Anuarul Muzeului Marinei Romane, VII, pp.125-133, Constanta, 2004.

[39] Bounegru, O., Trafiquants et navigateurs sur le Bas-Danube et dans le Pont Gauche, Wiesbaden, 2007.

[40] Bounegru, O., Studies on the Pontic and Aegean Economy, Demiurg: Iasi, 2009.

[41] Bounegru, O., Romanescu, G., Alexianu, M., Dumitrache, I. \& Vasiliniuc, I., Hinterland and site catchment studies at Histria on the Black Sea coast, Romania, Antiquity, 083(322) Online, 2009. http://www.antiquity.ac.uk/projgall/bounegru322/

[42] [Pârvan, V., Salsovia, Literary dialogues, XL(10), pp.962-975, 1906a.

[43] Pârvan, V., Salsovia, Literary dialogues, XL(11), pp.1017-1040, 1906b.

[44] Suceveanu, A., Zahariade, M., Topoleanu, F. \& Poenaru-Bordea, G., Halmyris I, Nereamia Napocae: Cluj-Napoca, 2003.

[45] Ascher, F., Tourism. Transitional Corporations and Cultural Identities, UNESCO: Paris, 1985.

[46] Danube Delta Biosphere Reservation Administration, Access rules on the territory of the Danube Delta Biosphere Reservation, Tulcea, 2010. 